\title{
Correlation of Nitric Oxide Synthase Expression with Changing Patterns of Axonal Projections in the Developing Visual System
}

\author{
Cheri V. Williams, ${ }^{a}$ Daniel Nordquist, and Steven C. McLoon \\ Department of Cell Biology and Neuroanatomy, University of Minnesota, Minneapolis, Minnesota 55455
}

\begin{abstract}
A precise pattern of connections between the retina and central visual nuclei in the brain is established during development. Activity-dependent presynaptic mechanisms and NMDA receptor-mediated postsynaptic mechanisms are thought to play important roles in this developmental process. A model proposed for production of the newly described neurotransmitter, nitric oxide, involves presynaptic activity and activation of postsynaptic NMDA receptors. If present in the developing visual system, nitric oxide could represent a form of retrograde communication from postsynaptic to presynaptic cells that mediates the formation of the proper pattern of connections. This study used the diaphorase histochemical technique to detect the presence of nitric oxide synthase (NOS), the enzyme responsible for the production of nitric oxide, in the developing chick optic tectum. Results from this study showed that NOS is present in the developing tectum and that its expression coincides temporally with innervation by retinal axons. NOS expression reaches a peak at the time that refinement of the initial pattern of connections is occurring. WGA/HRP labeling of retinal axons confirmed that processes of NOS-positive cells in the tectum extend well into the area of the ingrowing retinal axons. Histochemical results from eyeless chick embryos indicate that NOS expression is dependent on the presence of retinal axons, which suggests that retinal axons synapse on cells that express nitric oxide. Northern blot analysis using a cDNA probe to NOS from rat brain verified the histochemical results. These results are consistent with nitric oxide having a role in development of the proper pattern of connections in the chick retinotectal system.
\end{abstract}

[Key words: nitric oxide, retinotectal, plasticity, NADPH diaphorase, specificity, development, visual system]

Normal function of the nervous system depends on specific patterns of synaptic connections between defined groups of neurons. For example, in the visual system, retinal ganglion cell axons project to the primary visual nuclei in the brain in a retinotopic pattern. This precise pattern of connections arises during development of warm-blooded species from a roughly

\footnotetext{
Received March 29, 1993; revised Aug. 26, 1993; accepted Sept. 2, 1993.

We thank Drs. David Bredt and Solomon Snyder (John Hopkins University) for providing the cDNA probe to nitric oxide synthase. This work was supported by NIH Grants EY05371, EY06309, EY07133, and EY09537.

Correspondence should be addressed to Steven C. McLoon, Department of Cell Biology and Neuroanatomy, University of Minnesota, 4-135 Jackson Hall, 321 Church Street SE, Minneapolis, MN 55455.

a Present address: Department of Anatomy and Neurobiology, Colorado State University, Fort Collins, CO 80523.

Copyright (C) 1994 Society for Neuroscience $0270-6474 / 94 / 141746-10 \$ 05.00 / 0$
}

ordered prepattern (e.g., McLoon, 1982; O'Leary et al., 1986; Nakamura and O'Leary, 1989; Simon and O'Leary, 1992). This prepattern lacks the topographic precision of the mature pattern and includes many axons projecting inappropriately within nuclei, to inappropriate nuclei, or to the inappropriate side of the brain. Through a process of refinement, these inappropriate connections are eliminated or corrected, resulting in the mature pattern of connections.

The mechanisms responsible for this process of refinement are still poorly understood. It is well established that activitydependent mechanisms are involved in the refinement of the initial pattern of connections between the retina and primary visual nuclei (reviewed by Constantine-Paton et al., 1990; Shatz, 1990). When the spontaneous activity of presynaptic axons was blocked using the sodium channel blocker TTX, the mature pattern of connections was not established. Activation of postsynaptic cells, mediated at least in part via glutamate and NMDA receptors, also appears to be involved in the refincment process (Cline et al., 1987; Cline and Constantine-Paton, 1989, 1990; Debski et al., 1990; Simon et al., 1992). When NMDA receptors were blocked by direct application of NMDA antagonists to the optic tectum, the retinal projection did not undergo refinement. Involvement of postsynaptic neurons in the refinement of the pattern of connections made by the presynaptic neurons implies that postsynaptic cells communicate with presynaplic axons. The nature of the message that mediates the retrograde communication from postsynaptic to presynaptic cells is not known.

Nitric oxide has characteristics making it an appealing candidate for a retrograde neuronal messenger (reviewed by Garthwaite, 1991; Bredt and Snyder, 1992). Nitric oxide has been shown to have transmitter-like functions in the brain. It is released from a limited population of cells in response to glutamate activation of NMDA receptors. The soluble nature of nitric oxide allows it to cross cell membranes by diffusion, obviating the need for vesicular release. Nitric oxide can lead to changes in the level of cGMP in cells that respond to nitric oxide, and cGMP has been linked to changes in axon extension and retraction, essential activities for modifying patterns of neuronal connections. Additionally, nitric oxide has been suggested to be an important retrograde messenger in neuronal plasticity in studies of long-term potentiation (LTP) in the adult hippocampus (Schuman and Madison, 1991; Haley et al., 1992). Interestingly, LTP and the developmental refinement of connections appear to be similar processes. These characteristics of nitric oxide open the possibility that nitric oxide plays a role in the developmental refinement of neuronal connections (Gally et al., 1990).

The study presented here began to test the hypothesis that nitric oxide is involved in the refinement of retinotectal con- 
nections in the developing chick. During the developmental period between embryonic day 9 (E9) and E15 in the chick, the topographic precision of the retinotectal projection significantly improves and the transient ipsilateral retinotectal projection disappears (McLoon, 1982; McLoon and Lund, 1982; O'Leary et al., 1983; Thanos and Bonhoeffer, 1984; Nakamura and O'Leary, 1989; Williams and McLoon, 1991). If nitric oxide participates in this refinement process, it would be predicted that nitric oxide is expressed in tectal cells with which retinal axons interact during this period of refinement. Since the chemical nature of nitric oxide makes it difficult to study directly, this study examined the expression of nitric oxide synthase (NOS) in the developing tectum. This enzyme is responsible for production of nitric oxide (Bredt and Snyder, 1990; Dawson et al., 1991; Hope et al., 1991). It was found that NOS is transiently expressed by some tectal cells during the period of refinement, and the results imply an interaction between retinal axons and cells expressing NOS.

Preliminary results of this study were previously reported in abstract form (Williams et al., 1992).

\section{Materials and Methods}

Animals. Fertilized chicken eggs (pathogen-free White Leghorn crossed with Rhode Island Red) obtained from the University of Minnesota Poultry Center were incubated in an egg incubator at $37^{\circ} \mathrm{C}$ and $98 \%$ relative humidity. In order to obtain brains devoid of retinal axons, some embryos were removed from the shell and transferred to embryo culture chambers after $3 \mathrm{~d}$ of incubation (McLoon, 1985). Both eyes of the cultured embryos were destroyed by cauterization. These embryos were maintained in a forced-draft tissue culture incubator at $37^{\circ} \mathrm{C}, 95 \%$ relative humidity, and $1 \% \mathrm{CO}_{2}$. For labeling retinal axons, a separate group of embryos was cultured as described above except that the eyes were left intact.

Nitric oxide synthase (NOS) histochemistry. Embryos at various stages of development (E5-E21 and post hatching) were perfused through the heart with $4 \%$ paraformaldehyde in $0.1 \mathrm{~m}$ phosphate buffer (PB), $\mathrm{pH}$ 7.4. The brains were removed from the embryos and postfixed for $2 \mathrm{hr}$ in $4 \%$ paraformaldehyde/ $\mathrm{PB}$ followed by cryoprotection in $20 \%$ sucrose/ $\mathrm{PB}$ overnight at $4^{\circ} \mathrm{C}$. Frozen sections were cut with a cryostat at $16 \mu \mathrm{m}$ and mounted on gelatin-coated slides. Sections were stored at $-70^{\circ} \mathrm{C}$ until processed. Cells expressing NOS were identified by $\beta$-NADPH diaphorase histochemistry, following the protocol of Hope et al. (1991) with minor modifications. This was performed by incubating mounted sections with $1 \mathrm{~mm}$ NADPH, $0.5 \mathrm{~mm}$ nitroblue tetrazolium, $0.2 \%$ Triton $\mathrm{X}-100,0.1 \mathrm{M} \mathrm{PB}, \mathrm{pH} 7.4$, for $30 \mathrm{~min}$ at $37^{\circ} \mathrm{C}$. The sections were rinsed in distilled $\mathrm{H}_{2} \mathrm{O}$, dehydrated in a graded series of acetone, cleared in xylene, and coverslipped in Permount. Adjacent sections were stained with cresyl violet.

Sections from various ages were processed simultaneously in the same incubating buffer to control for variation with different batches of incubating buffer. A minimum of three brains were studied at each age, and at least 10 sections from each brain were processed for diaphorase histochemistry.

Labeling retinal axons. Retinal axons innervating the tectum were identified by injecting one eye of embryos with an anterogradely transported label, wheat germ agglutinin conjugated to horseradish peroxidase (WGA/HRP). Two microliters of $1 \% \mathrm{WGA} / \mathrm{HRP}$ in saline was injected into the right eye of E12 cultured embryos. The embryos were returned to the incubator for $24 \mathrm{hr}$. The embryos were then perfused through the heart with $0.5 \%$ glutaraldehyde/PB, followed by $2.5 \%$ glutaraldehyde/PB. The brains were removed from the embryos and sectioned as described above. The sections were reacted with tetramethyl benzidine (TMB) as described previously (McLoon, 1985), and WGA HRP-labeled retinal axons were visualized microscopically with polarized light. Adjacent sections were processed for NOS histochemistry or stained with cresyl violet.

Northern blot analysis. Expression of NOS mRNA in the developing chick optic tectum was analyzed by Northern blot hybridization according to procedures adapted from Sambrook et al. (1989). Briefly, RNA was isolated from frozen tecta by the guanidinium/CsCl method, fractionated for polyA ${ }^{+}$RNA on oligo-dT-cellulose, electrophoresed in a $1 \%$ agarose gel containing $6 \%$ formaldehyde, and blotted onto a nylon filter. DNA probes for hybridization were labeled with ${ }^{32} \mathrm{P}$-dCTP by random oligonucleotide priming. Blots were first hybridized with a cDNA probe to NOS from rat brain (Bredt et al., 199lb) and washed at low stringency. Following autoradiography, blots were stripped of the NOS probe in $95^{\circ} \mathrm{C} 10 \mathrm{~mm}$ Tris- $\mathrm{HCl} / 0.1 \%$ SDS and rehybridized at high stringency with a control probe, chick $\beta$-actin cDNA, to indicate the relative quantities of RNA in each lane.

\section{Results}

\section{Diaphorase histochemistry in normal embryos}

The goal of this study was to characterize the spatial and temporal patterns of nitric oxide expression in the developing chick optic tectum. More specifically, the purpose of this study was to determine whether nitric oxide is expressed by tectal cells during the period of activity-dependent refinement in the pattern of retinotectal connections and whether the spatial distribution of nitric oxide-producing tectal cells is consistent with a possible function of influencing retinal axons.

With a half-life of less than $6 \mathrm{sec}$, direct visualization of nitric oxide is difficult. NOS, the enzyme responsible for production of nitric oxide, can, however, be detected by the NADPH diaphorase histochemical procedure (Bredt et al., 1991a; Dawson et al., 1991; Hope et al., 1991; Blottner and Baumgarten, 1992). This assay was utilized in the present study to identify NOS activity in the developing chick optic tectum at various stages of development. Throughout the remainder of this article, NADPH diaphorase-positive cells will be interchangeably referred to as diaphorase-positive cells, diaphorase-stained cells, or NOS-positive cells.

The results from the present study are categorized into age groups for convenience of description. The changes during development took place continuously and the age groupings should not be misconstrued as distinct stages. The laminar designations in the tectum used here conform to that of LaVail and Cowan (1971).

Embryonic days 5-7. NOS-positive cells were found only in the neuroepithelial layer of the tectum from E5 to E7 (not shown). The neuroepithelial layer sits deep in the tectum, adjacent to the ventricle. It could be clearly distinguished as two layers by cresyl violet staining and by diaphorase histochemistry: a celldense layer, nearest the ventricle, and an overlying cell-sparse layer. NOS-positive cells were confined primarily to the cellsparse layer. The stained cells were stellate shaped and their processes extended toward the ventricle. The majority of these cells were darkly stained by diaphorase histochemistry. These cells persisted throughout development with the same staining intensity and relative distribution (e.g., Fig. 1). At later ages, these cells were present in tectal layers designated as $\mathrm{i}$ and ii. These layers were always positioned near the ventricle. Since cells in these layers do not directly interact with retinal axons, the deep NOS-positive cells will not be described for the older ages. Diaphorase-stained cells were not present in the more superficial layers of the tectum at these early ages.

Embryonic days 8-11. NOS-positive cells appeared in more superficial tectal layers on E8. These cells first appeared in rostral tectum (Fig. 1). Using the LeVail and Cowan (1971) nomenclature for E10 tectum, which E8 rostral tectum most closely resembles, NOS-positive cell bodies were present in layers iv, $\mathrm{v}$, and vi. These cells were darkly stained. More caudally, fewer of the superficial tectal cells were stained, and the staining became much fainter to the point where this staining was not 


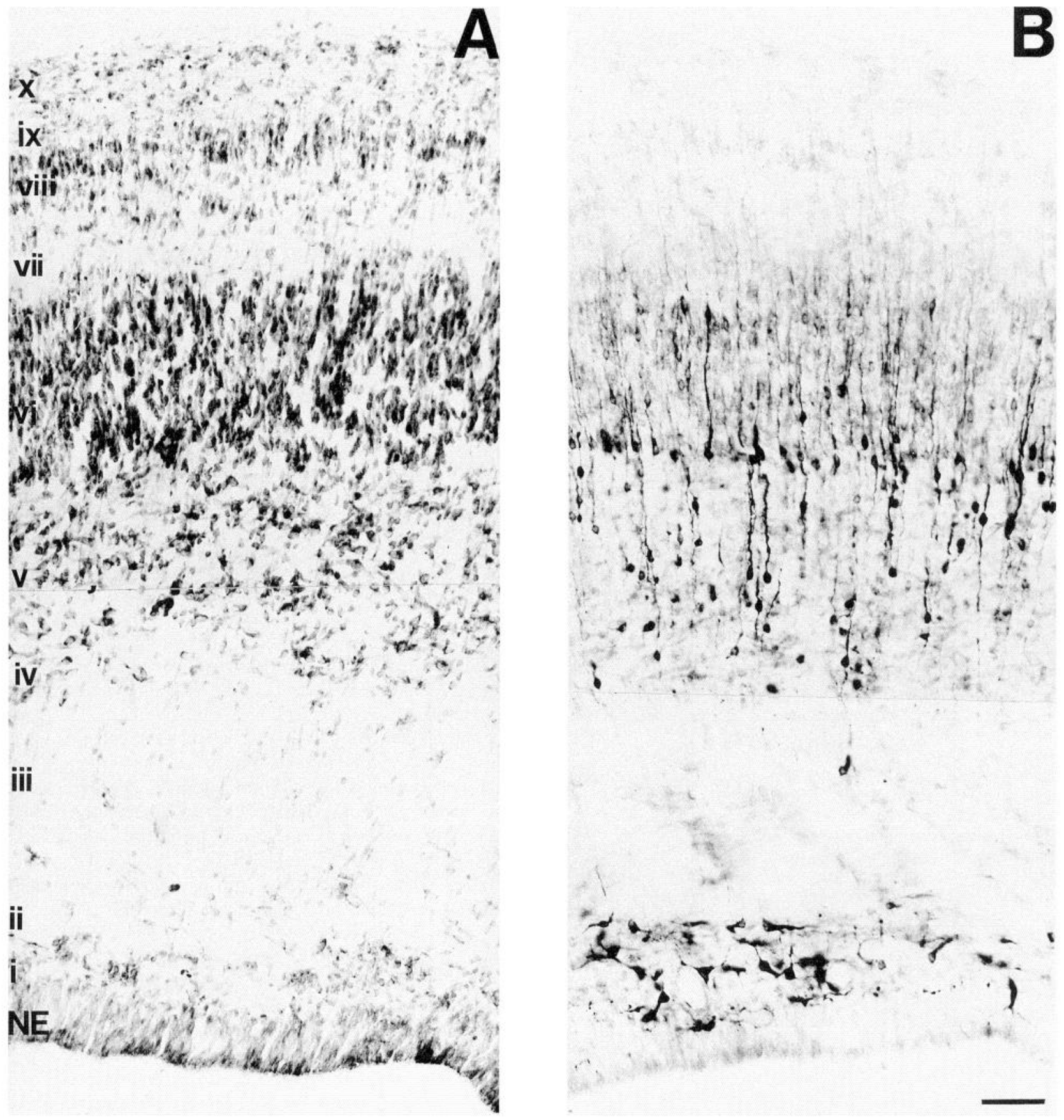

Figure 1. Histological localization of NOS in E8 rostral tectum. A, Bright-field photomontage of a cresyl violet-stained section of a tectum from an E8 embryo. $B$, Bright-field photomontage of NADPH diaphorase-stained section adjacent to $A$. Stellate-shaped, diaphorase-positive cells were found in layers $i$ and ii near the ventricular border of the tectum. Unipolar, diaphorase-positive cells appeared in the more superficial tectal layers. The cell bodies of these unipolar cells were confined to layers iv, v, and vi. Each cell had a darkly stained process that extended toward the pial surface. Scale bar, $50 \mu \mathrm{m}$.

detectable in the most caudal regions of the tectum (Fig. 2). Thus, the staining pattern in the caudal regions of the tectum at this age was the same as that seen in all areas of the E5-E7 tectum (i.e., only a deep population of cells were NOS positive).

NOS-positive cells appeared in the superficial tectal layers progressively more caudal in older embryos: The appearance of the superficial NOS-positive cells in more caudal tectum paralleled the invasion of retinal axons (McLoon, 1985). These NOS-positive cells appeared in the superficial layers of the tectum just after the arrival of retinal axons to the region. In older embryos beginning in the rostral tectum, the somas of these NOS-positive cells became restricted to layer vi of the tectum. A gradient of maturation from the more mature rostral tectum to the less mature caudal tectum was apparent at all embryonic ages examined.

The majority of the NOS-positive cells in the superficial tectal layers at E8 were unipolar with a radially oriented process directed toward the pial surface of the tectum (Fig. 1). Some of these processes could be traced into layer ix. Fine short extensions emanated from the radial processes. There were also a few 

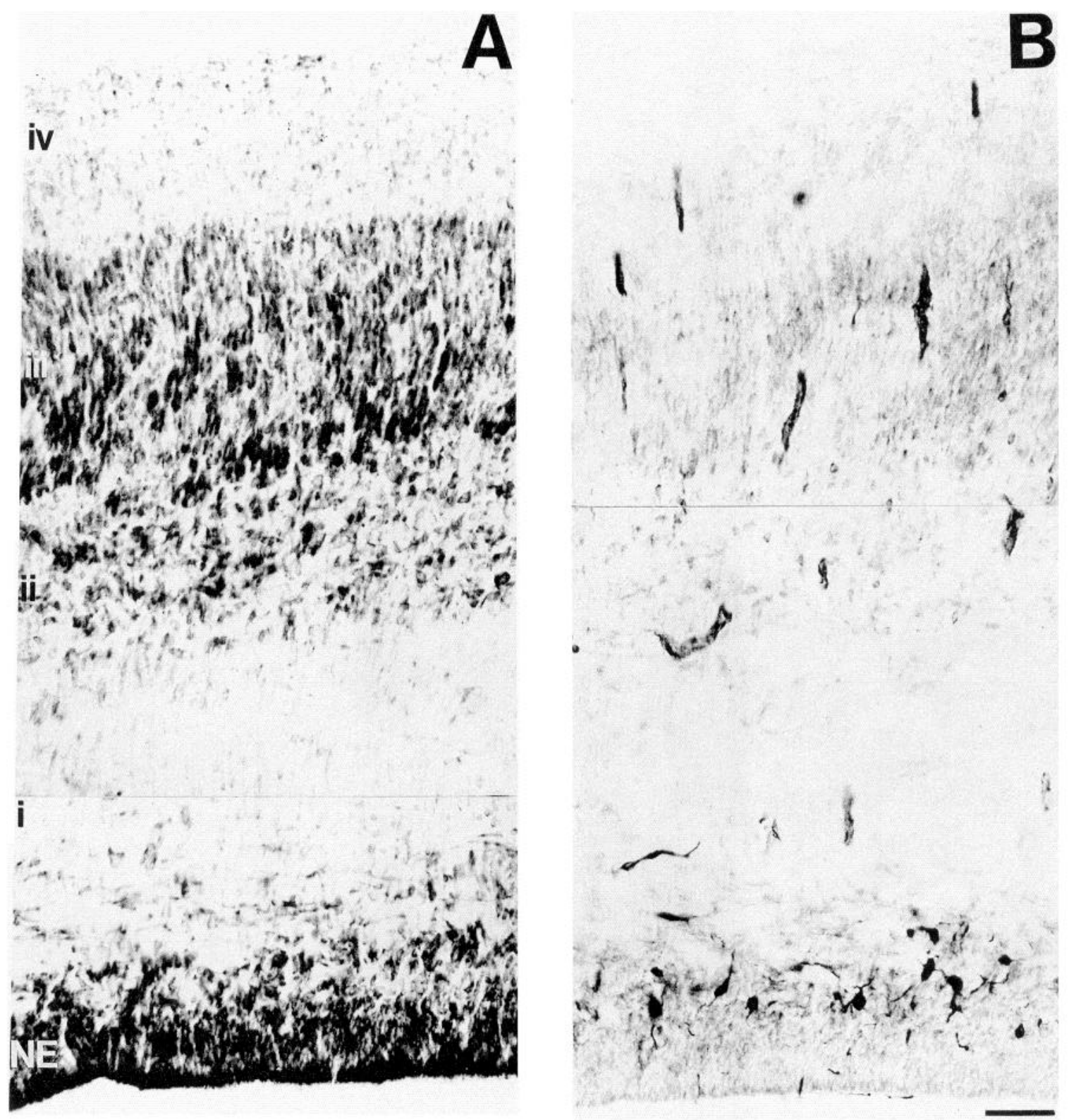

Figure 2. Histological localization of NOS in E8 caudal tectum. A, Bright-field photomontage of a cresyl violet-stained section of a tectum from an E8 embryo. $B$, Bright-field photomontage of NADPH diaphorase-stained section adjacent to $A$. Diaphorase staining was confined to the neuroepithelial $(N E)$ layers of the tectum, where stellate-shaped cells and their processes were darkly stained for diaphorase. Large blood vessels were also diaphorase positive throughout the thickness of the tectum. Scale bar, $50 \mu \mathrm{m}$.

bipolar cells scattered among the population of unipolar cells. At older ages, particularly as the cells became concentrated in layer vi, more of the stained cells appeared to be bipolar.

Large blood vessels were frequently diaphorase positive (Fig. 2). This is consistent with previous studies showing that nitric oxide is associated with blood vessels (Garthwaite, 1991).

Embryonic days 12-15. The peak expression of NOS in the superficial layers of the tectum was seen from E12 to E15. Many of the NOS-positive cells were bipolar with radially oriented processes (Fig. 3). The somas of these NOS-positive bipolar cells were concentrated in layer vi at these ages. A darkly stained apical process extended toward the pial surface and could often be traced into layer $\mathrm{xi}$, the layer immediately below the stratum opticum. Many of the apical processes were seen to bifurcate, with both processes extending toward the tectal surface. Short, fine branches were common on the large apical processes. A more faintly stained radial process also extended from these cells toward the ventricular surface. These were unbranched, fine processes, roughly uniform in diameter along their lengths, characteristics typical of axons. These deep processes generally could not be followed far from the cell bodies. In a few cases, they appeared to join a large fiber tract in layer iii. The intensity of the staining for NOS in these cells was much stronger than at the earlier ages, and the stained cells were much more densely packed.

Two other populations of NOS-positive cells appeared during this developmental period (Fig. 3). These cells were faintly stained, regularly spaced, stellate-shaped cells present in layers viii and $\mathrm{x}$ (according to LaVail and Cowan nomenclature for E14). The cells in layer $x$ were more darkly stained than those 

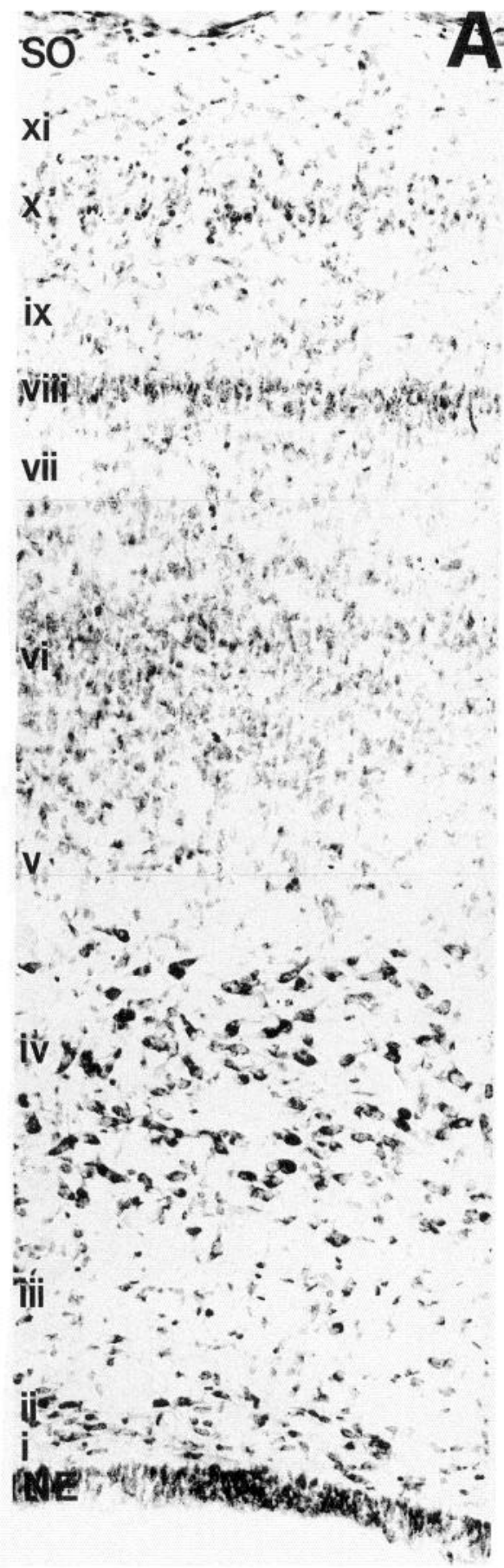

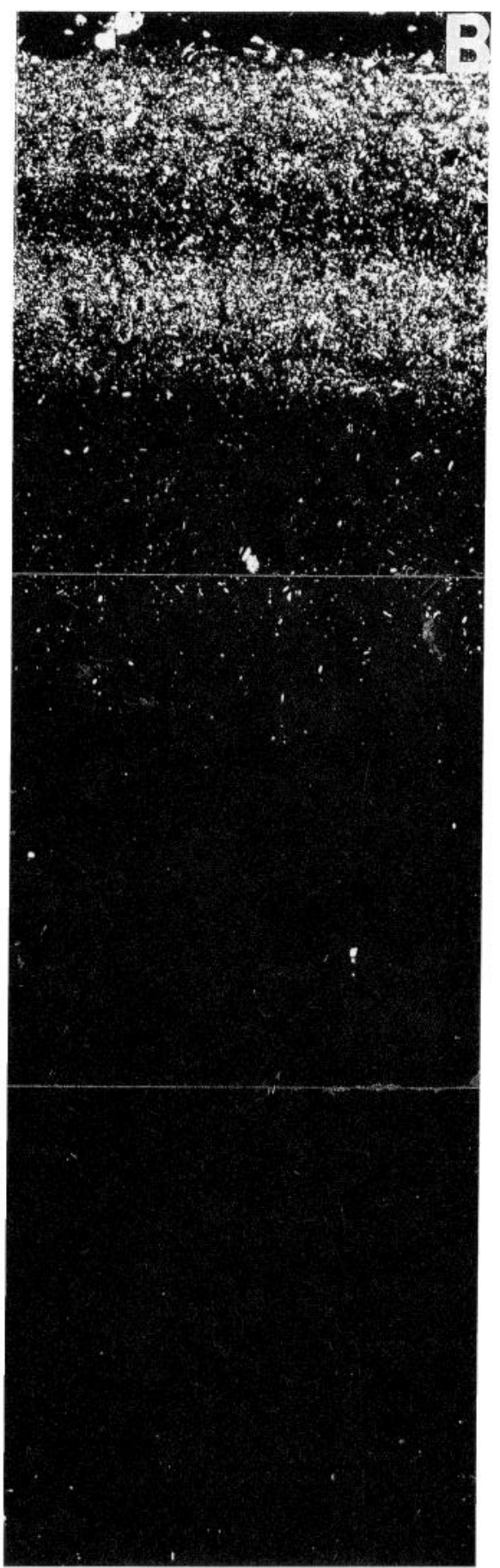

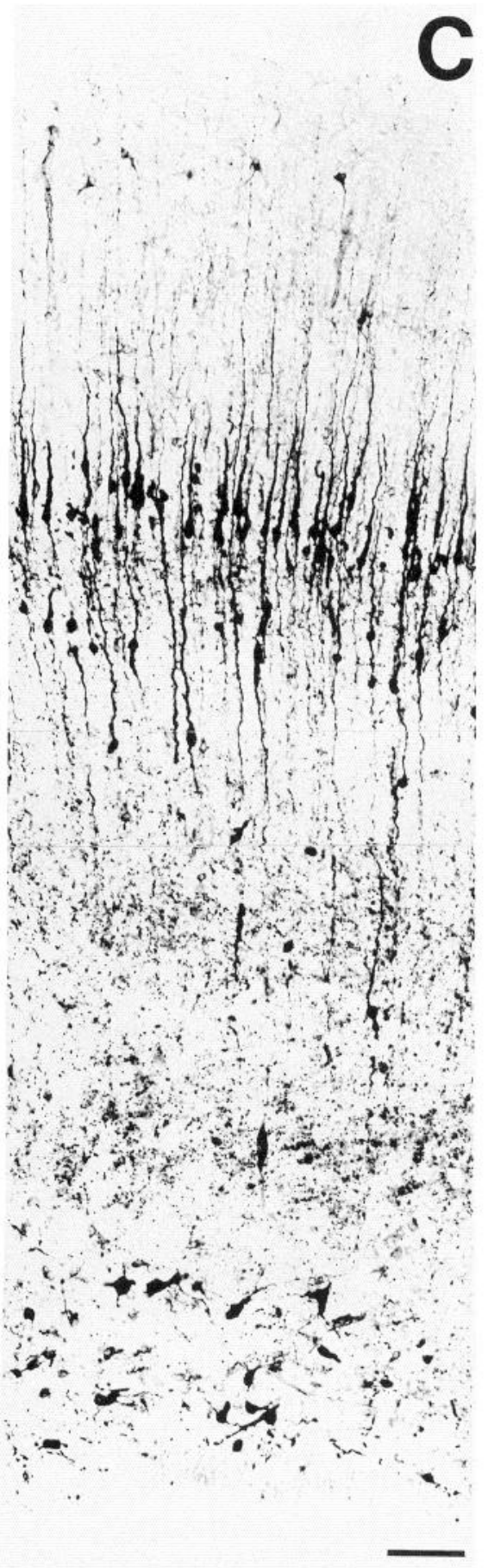

Figure 3. Histological localization of NOS in E13 tectum. A, Bright-field photomontage of a cresyl violet-stained section of a tectum from an E13 embryo. B, Dark-field photomontage showing WGA/HRP-labeled retinal axons. WGA/HRP-labeled axons (visible as white specks) penetrated from the striatum opticum $(S O)$ well into the superficial tectal layers. $C$, Bright-field photomontage of NADPH diaphorase-stained section depicting peak NOS expression. Diaphorase-positive stellate cells were present in layers i and ii. Many diaphorase-positive bipolar cells were concentrated in layer vi. The processes of these cells could be followed toward the pial surface of the tectum. Another group of diaphorase-positive stellate cells were found in layers viii and $\mathrm{x}$. Comparison of $B$ and $C$ shows that diaphorase-positive processes of tectal cells extended into the layers in which retinal axons terminated. Scale bar, $50 \mu \mathrm{m}$.

in layer viii. The cells in both layers were in relatively low density. The processes of these cells extended into adjacent tectal layers, where they often branched. Most of these cells had several stained processes emanating from the cell body. Because of the characteristics of the branching pattern, these processes were typical of dendrites. No stained processes were seen on these cells that would be described as an axon.

Terminals of retinal axons appeared to be coincident with NOS-positive cell processes. Previous studies using a variety of techniques showed that retinal axons penetrate the superficial 


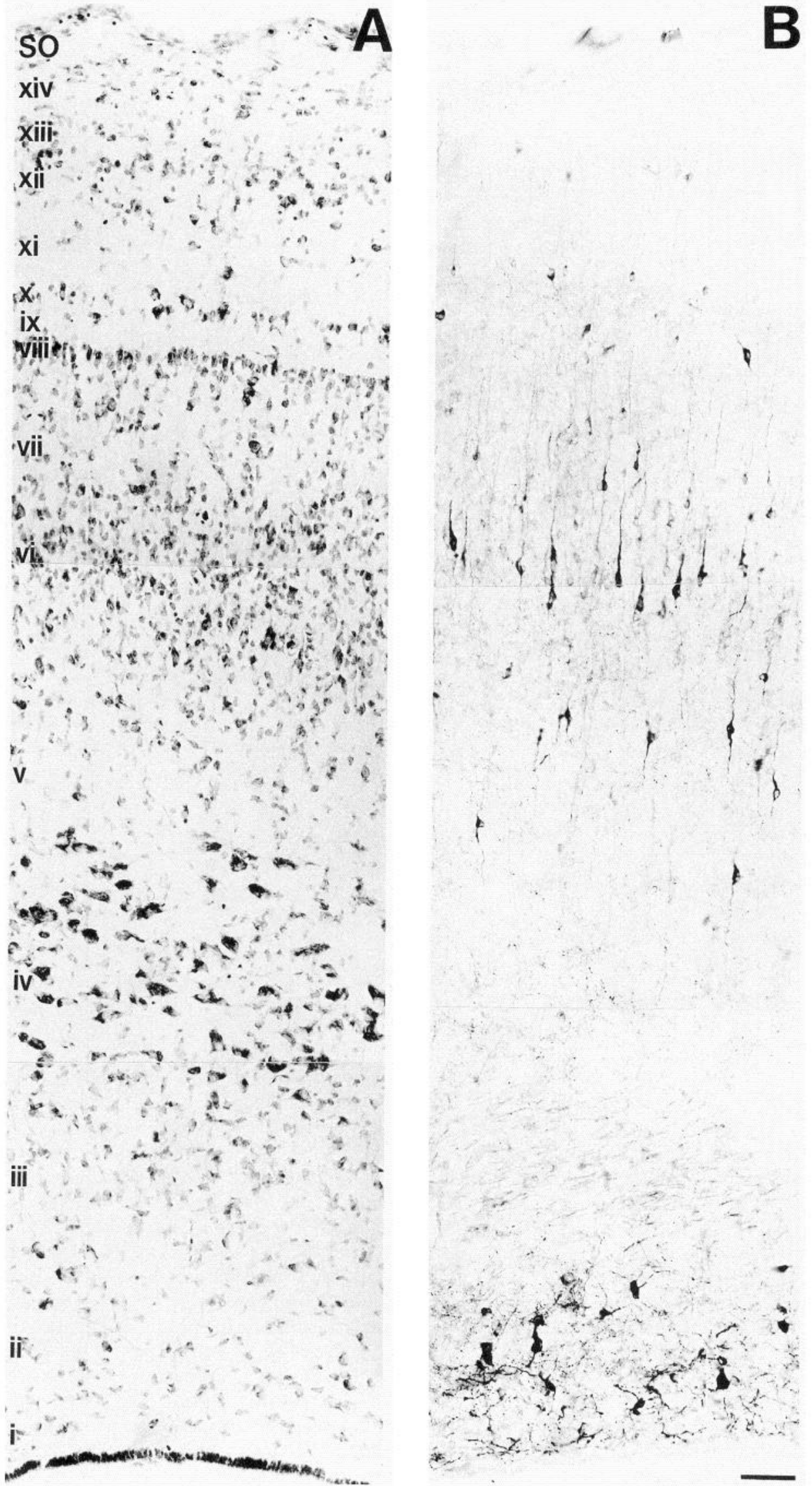

Figure 4. Histological localization of NOS in E16 tectum. $A$, Bright-field photomontage of a cresyl violet-stained section of a tectum from an E16 embryo. $B$, Bright-field photomontage of NADPH diaphorase-stained section adjacent to $A$. There was an overall reduction in NOS expression in the superficial tectal layers compared to the E12-E15 embryos. Unipolar cells in layers $\mathrm{v}$ and $\mathrm{vi}$ and stellate cells in layers viii, $\mathrm{x}$, and xii were faintly stained. Darkly stained diaphorase-positive stellate cells were still found in layers i and ii. Scale bar, $50 \mu \mathrm{m}$. 
Figure 5. Histological localization of NOS in E13 "eyeless" tectum. $A$, Brightfield photomontage of a cresyl violetstained section of a tectum from an anophthalmic E13 embryo. B, Bright-field photomontage of NADPH diaphorasestained section adjacent to $A$. There was a substantial reduction in the expression of NOS in the superficial tectal layers in eyeless embryos compared to normal embryos of the same age. Scale bar, $50 \mu \mathrm{m}$.

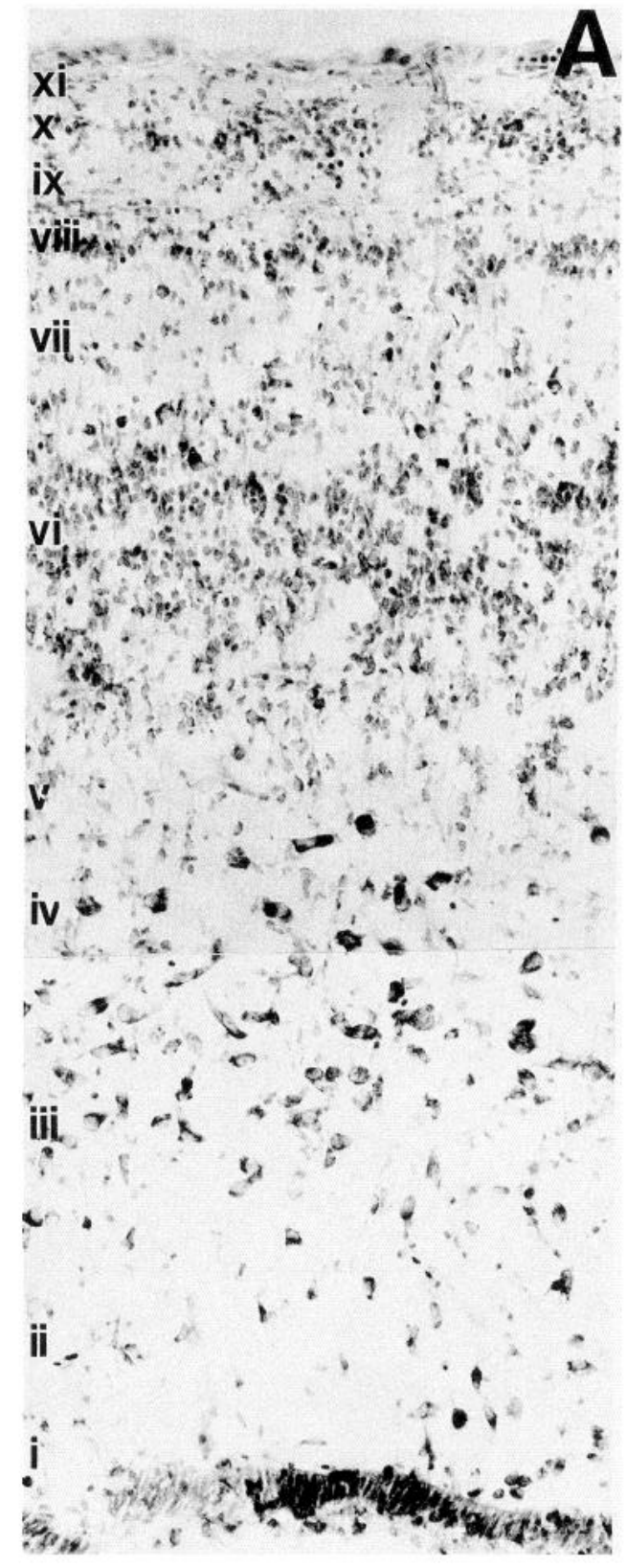

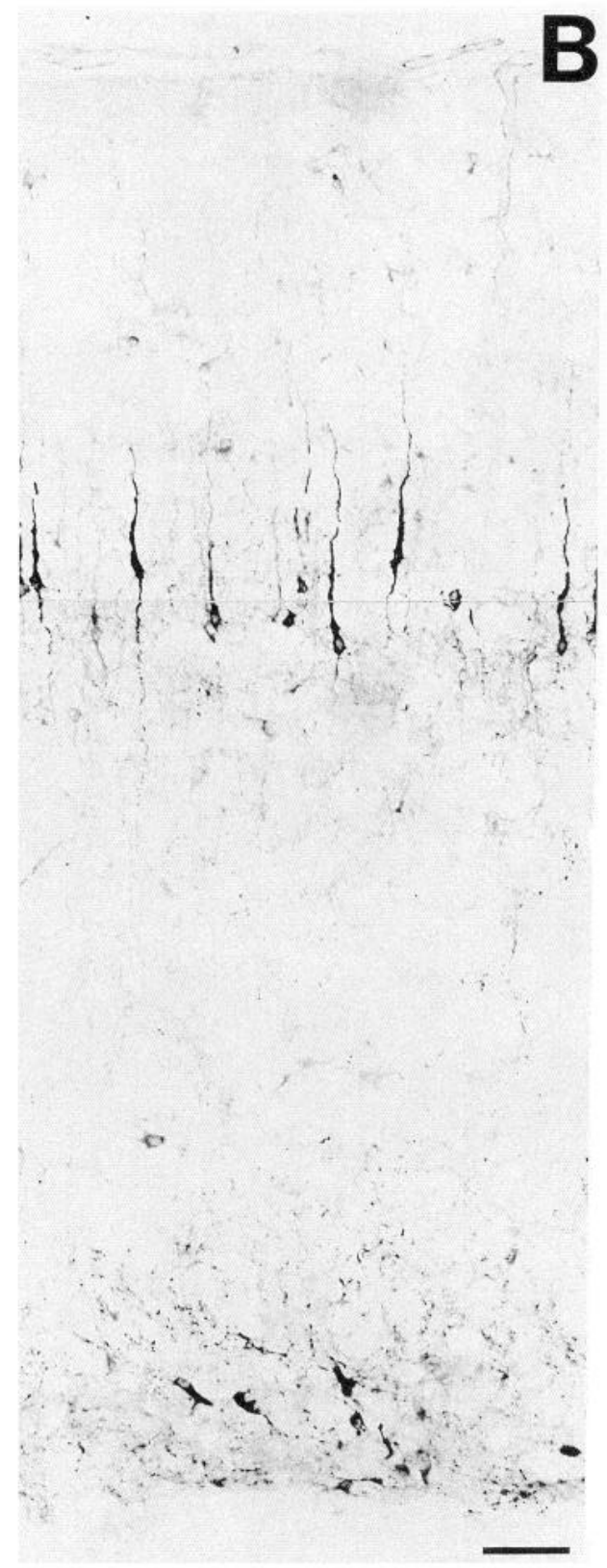

tectal layers during this peak period of NOS expression (LaVail and Cowan, 1971; Crossland et al., 1974; Rager, 1980; McLoon, 1985). To investigate the possibility of interaction between retinal axons and the processes of NOS cells, the retinal axons were labeled by intraocular injection of WGA/HRP. Adjacent sections of the brains of these embryos were processed for diaphorase histochemistry and HRP histochemistry. HRP label was present as deep as layer vii in the tectum of E13 embryos (Fig. $3 B$ ). The labeling pattern suggested arborizations of the retinal axons in tectal layers viii-xi. Comparison with the diaphorase staining showed that the layers with arborizations of retinal axons were the layers with the most extensive network of NOSpositive cell processes. Thus, the processes of cells expressing NOS and the termination of retinal axons appeared to be coextensive. This is consistent with the possibility that retinal axons synapse with tectal cells that express NOS.

Embryonic day 16 to hatching. From E16 to hatching there was a gradual and significant reduction in NOS expression in the superficial tectal layers (Fig. 4). Both the staining intensity and the density of diaphorase-stained cells in layer vi, which correlates with lamina $\mathrm{h}$ of the stratum griseum superficiale (SGFS) in hatched chicks, were reduced. The cell processes directed toward the ventricular surface were generally not stained, and the processes directed toward the pial surface were so faintly stained that they could not be followed far from the cell bodies. Although it was not quantified, the reduction in the density of NOS-positive cells (compared to E12-E15) appeared to be too great to be accounted for simply by an increase in the space between labeled cells associated with the growth of the tectum. This was most evident in hatched chicks, where very few labeled cells remained in this layer. There also appeared to be a reduction in the staining intensity and density of cells in layers viii and $\mathrm{x}$, which correlates with laminae $\mathrm{g}$ and $\mathrm{e}$ of the SGFS in hatched chicks. This reduction was not as dramatic as that seen 
in layer vi. Diaphorase-stained cells also appeared in layer xii in these older chicks (lamina $\mathrm{c}$ of the SGFS after hatching). This is a very sparse population of faintly stained cells.

\section{Diaphorase histochemistry in eyeless embryos}

The correspondence between the invasion of retinal axons and the appearance of NOS-positive cells in the superficial tectal layers suggested that retinal axons may be involved in the induction of NOS expression. If this were the case, it would further support the suggestion that retinal axons interact with NOSpositive cells. In order to determine the importance of retinal axon innervation for the activation of NOS in the tectum, tecta devoid of retinal axons were processed for diaphorase histochemistry during the peak period of NOS expression (Fig. 5). The NOS-positive stellate cells found deep in the tectum in layers $\mathrm{i}$ and ii in normal E13 embryos were present in tecta of eyeless embryos, and this staining was comparable to that of normal embryos in terms of the number of cells and density of staining. The prominent population of NOS-positive bipolar cells in layer vi of normal E13 tectum (Fig. 3) was dramatically reduced in tecta devoid of retinal axons (Fig. 5). The intensity of diaphorase staining in these cells was greatly reduced, as was the number of stained cells. Cell bodies were stained, but the processes of these cells could only be followed toward the pial surface for a short distance. The more superficial stellate cells in layers viii and $x$ of normal tectum were not stained in sections of eyeless tectum. This reduction in NOS expression in the absence of retinal axons is consistent with the suggestion that retinal axons have a role in the induction of NOS activity in the developing optic tectum.

\section{Northern blot analysis of NOS expression}

Analysis of tectal RNA for NOS expression confirmed the diaphorase results. Northern blots of polyA ${ }^{+}$RNA isolated from tecta of different aged embryos were hybridized with a cDNA probe to rat brain NOS (Fig. 6A) (Bredt et al., 1991b). NOS message was virtually absent in RNA from E6 tectum, and only a faint band was seen with E8 RNA. Samples from E12 tectum showed a single, heavily labeled band, which was the peak expression level observed. A reduced level of NOS message was detected in RNA from E16 tectum. The size of the message was approximately 10 kilobases, which is similar to that determined for rat brain NOS (Bredt et al., 1991b). There was a significant reduction in the amount of NOS message in RNA samples from E12 eyeless embryos compared to that of normal E12 embryos. This suggests that retinal axons regulate NOS activity at the level of transcription rather than at the level of translation or enzyme activation. The blots were stripped of label and reprobed with a cDNA for chick $\beta$-actin, which indicated that similar amounts of total message were used for each sample (Fig. 6B). The Northern blots showed that the levels of NOS message in the chick tectum paralleled the histochemical staining patterns seen with diaphorase at the different ages.

\section{Discussion}

The aim of this study was to characterize the spatial and temporal pattern of NOS expression in the developing chick optic tectum. NADPH diaphorase histochemistry showed that NOSpositive cells are present in the developing tectum. The histochemical assay for detection of NADPH diaphorase activity has been shown to identify NOS-positive cells in the brain (Bredt et al., 1991a; Dawson et al., 1991; Hope et al., 1991; Blottner

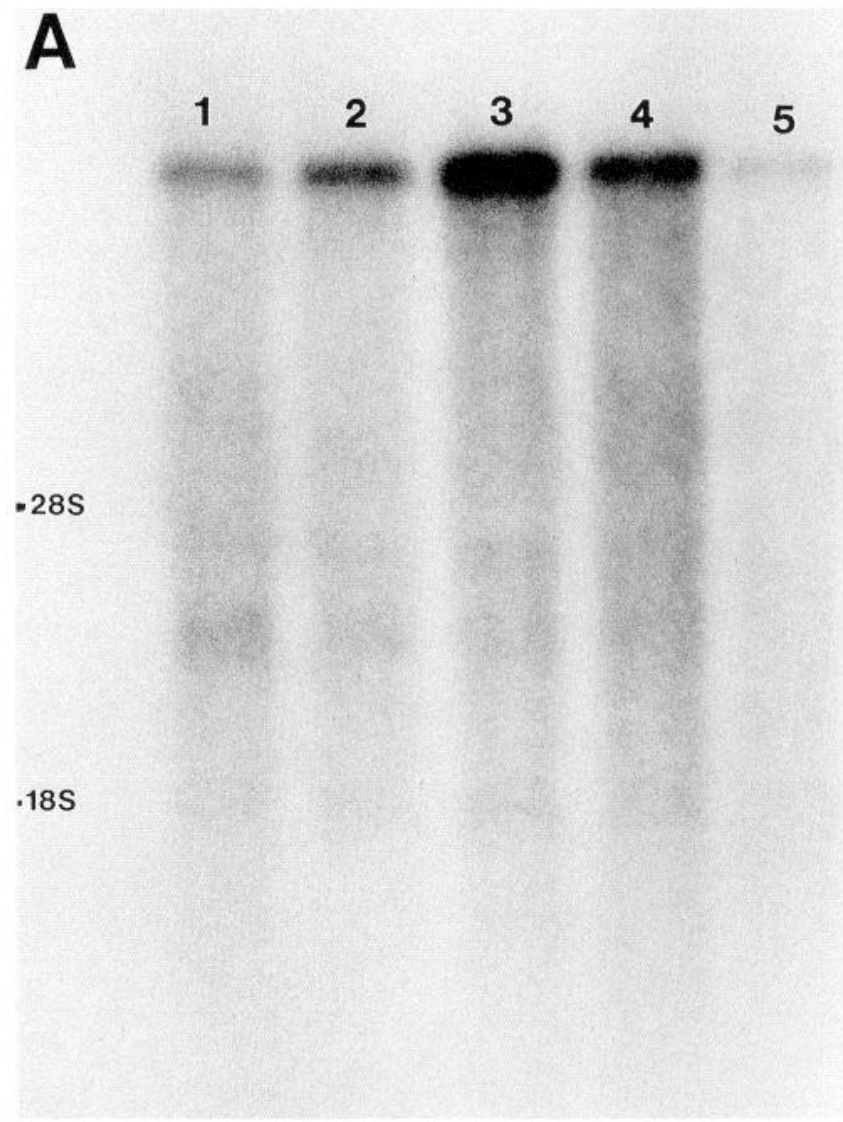

B

$.28 S$

$.18 S$

Figure 6. A, Northern blot of polyA ${ }^{+}$RNA isolated from tecta of E6 (lane 1), E8 (lane 2), E12 (lane 3), E16 (lane 4), and E12 eyeless (lane 5 ) embryos and hybridized with a cDNA probe to rat brain NOS. The developmental expression of NOS demonstrated by Northern blot paralleled the pattern of NOS expression demonstrated histochemically. $B$, The same blot as shown in $A$ reprobed with a cDNA probe to chicken $\beta$-actin to indicate the relative amounts of mRNA in each lane.

and Baumgarten, 1992). Bredt et al. (1991a), using an antibody to NOS from rat brain, oligonucleotide probes to rat NOS, and NADPH diaphorase histochemistry, demonstrated that NOS protein and message is coincident with NADPH diaphorase activity. In fact, there were no cells with NADPH diaphorase activity in rat brain that were not also NOS positive. Based on these studies in rat, it was concluded that cells visualized in 
developing chick tectum with NADPH diaphorase activity expressed NOS.

Northern blot analysis further supports the conclusion that NOS is expressed in the developing chick tectum. The cDNA probe to rat NOS (Bredt et al., 1991 b) was used to probe Northern blots prepared with polyA ${ }^{+}$RNA from chick tectum. The probe recognized a band of approximately the same size as that seen with rat RNA. The relative changes in the levels of NOS expression, as suggested by diaphorase activity, were consistent with the density of the positive bands in the Northern blots. Thus, the rat cDNA probe most likely recognized a chick NOS gene expressed in the developing optic tectum with significant sequence homology to rat NOS.

NOS appeared to be expressed in dendrites of tectal neurons. Although no marker specific for neurons was used to identify the tectal cells that expressed NOS, these cells were not similar in shape to glial cells identified in the developing chick tectum with glial-specific markers (Gray and Sanes, 1991, 1992). The morphological characteristics of the NOS-positive cells, particularly the bipolar cells in layer vi, were typical of neurons. These cells had tapering apical processes with many fine branches as onc would cxpect for dendrites. During the pcak pcriod of NOS expression, axon-like basal processes also showed variable amounts of diaphorase activity. These were fine, nontapering, and generally nonbranching processes, which could sometimes be traced into a fiber bundle.

The appearance of NOS expression in the superficial layers of the chick tectum paralleled the arrival of retinal axons. The expression of NOS in a given region of the tectum, however, lagged slightly behind the invasion of retinal axons into that region. NOS was not expressed in the superficial layers of the tectum prior to the arrival of retinal axons. The first retinal axons arrive in the rostral tectum on E6 (McLoon, 1985). The first NOS-positive cells were seen in the superficial layers of the rostral tectum on E8. Between E6 and E12, retinal axons grow toward the caudal pole of the tectum (McLoon, 1985). During the period from E8 to E14, NOS-positive cells also appeared in progressively more caudal regions of the tectum. The parallel between the arrival of retinal axons and the increase in NOS expression suggests that retinal axons are in some way involved in regulation of NOS expression.

Tecta devoid of retinal axons were examined for NOS expression to explore further the relationship between NOS expression and retinal axon innervation. Histochemical analysis of tecta from these embryos revealed a significant reduction in the number of cells with diaphorase activity and in the intensity of staining in individual cells in superficial tectal layers as compared to normal tecta of the same age. Northern blot analysis also revealed a significant reduction in NOS expression in the tecta of "eyeless" embryos. These results demonstrated that the expression of NOS in the superficial layers of the developing tectum is dependent on retinal innervation.

The basis for the relationship between NOS expression and retinal axon innervation in the tectum is not clear. The lack of retinal innervation could have reduced neurogenesis, and the cells that normally express NOS may have failed to be born. This, however, seems unlikely since studies have shown that eye removal in early development does not effect neurogenesis (Cowan et al., 1968; Kelly and (owan, 1972). Alternatively, NOS-producing cells could have died in the absence of normal innervation. Increased neuronal death has been observed in the tectum in the absence of retinal innervation, but this does not begin in rostral tectum until E12, well after NOS is normally expressed (Kelly and Cowan, 1972). It is more likely that the NOS-producing cells are present in eyeless embryos and that retinal axons result in an upregulation of NOS expression in cells in the superficial tectal layers. Administration of glutamate, a putative transmitter substance of retinal axons, to the tecta of eyeless embryos resulted in a rapid increase in the number of cells with diaphorase activity in the superficial tectal layers (D. Waid, C. V. Williams, and S. C. McLoon, unpublished observation). Furthermore, the Northern blot analysis of NOS message during development and in eyeless embryos suggests that retinal axons regulate, at least in part, at the level of transcription of the NOS gene rather than at translation or activation of the enzyme.

The finding that NOS expression is dependent on retinal innervation implies that there is an interaction between the ingrowing retinal axons and the NOS-positive tectal cells. Histological analysis clearly demonstrated that processes of NOSpositive cells ramified in the plexiform layers where retinal axons form the majority of their synapses (LaVail and Cowan, 1971). The codistribution of NOS-positive cell processes and retinal axons was further established by anterogradely labeling the retinal axons with WGA/HRP and processing adjacent sections for HRP and diaphorase histochemistry. The bipolar cells of tectal layer vi extended their NOS-positive apical processes through all layers receiving retinal innervation. The small stellate cells of layers viii, $x$, and xii extended their NOS-positive processes into the adjacent layers, which are known to be the primary syndptic sites of the retinal axons. It cannot be concluded from this data that retinal axons synapse directly on cells expressing NOS, but this seems likely. Given the likelihood that nitric oxide is generated as a result of the presence of NOS (Garthwaite, 1991; Bredt and Snyder, 1992), it is likely that developing retinal axons are exposed to nitric oxide.

The spatial and temporal pattern of NOS expression is consistent with the possibility that nitric oxide has a role in the refinement of the pattern of retinotectal connections in the developing chick visual system. Transient connections in the chick retinotectal system are eliminated between E10 and E15 (McLoon, 1982; McLoon and Lund, 1982; O'Leary et al., 1983; Thanos and Bonhoeffer, 1984; Nakamura and O'Leary, 1989; Williams and McLoon, 1991). NOS expression, and presumably nitric oxide production, reached a peak during this period of development. It is interesting that at the end of the period of refinement, a time by which the mature pattern of connections is established, NOS expression began to decline. The actual functional significance of NOS and nitric oxide in the developing visual system remains to be determined, but the intriguing possibility remains that nitric oxide serves as a retrograde messenger from tectal neurons to the retinal axons. A preliminary report suggests that inhibition of nitric oxide synthesis in the developing chick reduced the loss of a transient retinotectal projection, which further supports this hypothesis ( $\mathrm{Wu}$ and McLoon, 1993).

In summary, this study demonstrated that (1) NOS is expressed by cells in the developing chick tectum, (2) NOS expression in the superficial layers of the tectum appears to be regulated by retinal axons, (3) retinal axons are in a position to interact with the processes of the NOS-positive cells, (4) NOS is present at the right time and in the right place for nitric oxide to have a role in the refinement of the developing retinotectal projection, and (5) the level of NOS expression in the superficial 
layers of the tectum is reduced toward the end of the period of visual system development.

\section{References}

Blottner D, Baumgarten H-G (1992) Nitric oxide synthetase (NOS)containing sympathoadrenal cholinergic neurons of the rat IML-cell column: evidence from histochemistry, immunohistochemistry and retrograde labeling. J Comp Neurol 316:45-55.

Bredt DS, Snyder SH (1990) Isolation of nitric oxide synthetase, a calmodulin-requiring enzyme. Proc Natl Acad Sci USA 87:682-685.

Bredt DS, Snyder SH (1992) Nitric oxide, a novel neuronal messenger. Neuron 8:3-11.

Bredt DS, Glatt CE, Hwang PM, Fotuhi M, Dawson TM, Snyder SH (1991a) Nitric oxide synthase protein and mRNA are discretely localized in neuronal populations of the mammalian CNS together with NADPH diaphorase. Neuron 7:615-624.

Bredt DS, Hwang PM, Glatt CE, Lowenstein C, Reed RR, Snyder SH (1991b) Cloned and expressed nitric oxide synthase structurally resembles cytochrome P-450 reductase. Nature 351:714-718.

Cline HT, Constantine-Paton M (1989) NMDA receptor antagonists disrupt the retinotectal topographic map. Neuron 3:413-426.

Cline HT, Constantine-Paton M (1990) NMDA receptor agonist and antagonists alter retinal ganglion cell arbor structure in the developing frog retinotectal projection. J Neurosci 10:1197-1216.

Cline HT, Debski EA, Constantine-Paton M (1987) $N$-methyl-D-aspartate receptor antagonist desegregates eye-specific stripes. Proc Natl Acad Sci USA 84:4342-4345.

Constantine-Paton M, Cline HT, Debski E (1990) Patterned activity, synaptic convergence, and the NMDA receptor in developing visual pathways. Annu Rev Neurosci 13:129-154.

Cowan WM, Martin AH, Wenger E (1968) Mitotic patterns in the optic tectum of the chick during normal development and after early removal of the optic vesicle. J Exp Zool 169:71-92.

Crossland WJ, Cowan WM, Rogers LA, Kelly JP (1974) The specification of the retinotectal projection in the chick. J Comp Neurol 155:127-164.

Dawson TM, Bredt DS, Fotuhi M, Hwang PM, Snyder SH (1991) Nitric oxide synthase and neuronal NADPH diaphorase are identical in brain and peripheral tissues. Proc Natl Acad Sci USA 88:77977801.

Debski EA, Cline HT, Constantine-Paton M (1990) Activity-dependent tuning and the NMDA receptor. I Neurobiol 21:18-32.

Gally JA, Montague PR, Reeke GN, Edelman GM (1990) The NO hypothesis: possible effects of a short-lived, rapidly diffusible signal in the development and function of the nervous system. Proc Natl Acad Sci USA 87:3547-3551.

Garthwaite J (1991) Glutamate, nitric oxide and cell-cell signaling in the nervous system. Trends Neurosci 14:60-67.

Gray GE, Sanes JR (1991) Migratory paths and phenotypic choices of clonally related cells in the avian optic tectum. Neuron 6:211-225.

Gray GE, Sanes JR (1992) Lineage of radial glia in the chicken optic tectum. Development 114:271-283.

Haley JE, Wilcox GL, Chapman PF (1992) The role of nitric oxide in hippocampal long-term potentiation. Neuron 8:211-216.
Hope BT, Michael GJ, Knigge KM, Vincent SR (1991) Neuronal NADPH diaphorase is a nitric oxide synthase. Proc Natl Acad Sci USA 88:2811-2814.

Kelly JP, Cowan WM (1972) Studies on the development of the chick optic tectum. III. Effects of early eye removal. Brain Res 42:263-288.

LaVail JH, Cowan WM (1971) The development of the chick optic tectum. I. Normal morphology and cytoarchitectonic development. Brain Res 28:391-419.

McLoon SC (1982) Alterations in precision of the crossed retinotectal projection during chick development. Science 215:1418-1420.

McLoon SC (1985) Evidence for shifting connections during development of the chick retinotectal projection. J Neurosci 5:2570-2580.

McLoon SC, Lund RD (1982) Transient retinofugal pathways in the developing chick. Exp Brain Res 45:277-284.

Nakamura H, O'Leary DDM (1989) Inaccuracies in initial growth and arborization of chick retinotectal axons followed by course corrections and axon remodeling to develop topographic order. J Neurosci 9:37763795 .

O'Leary DDM, Gerfen CR, Cowan WM (1983) The development and restriction of the ipsilateral retinofugal projection in the chick. Dev Brain Res 10:93-109.

O'Leary DDM, Fawcett JW, Cowan WM (1986) Topographic targeting errors in the retinocollicular projections and their elimination by selective ganglion cell death. J Neurosci 6:3692-3705.

Rager G (1980) The development of the retinotectal projection in the chicken. Adv Anat Embryol Cell Biol 63:1-84.

Sambrook J, Fritsch EF, Maniatis T (1989) Molecular cloning: a laboratory manual. Cold Spring Harbor, NY: Cold Spring Harbor Laboratory.

Schuman EM, Madison DV (1991) A requirement for the intercellular messenger nitric oxide in long-term potentiation. Science 254:1504 1506.

Shatz CJ (1990) Impulse activity and the patterning of connections during CNS development. Neuron 5:745-756.

Simon DK, O'Leary DDM (1992) Development of topographic order in the mammalian retinocollicular projection. J Neurosci 12:12121232.

Simon DK, Prusky GT, O'Leary DDM, Constantine-Paton M (1992) $N$-methyl-D-aspartate receptor antagonists disrupt the formation of a mammalian neural map. Proc Natl Acad Sci USA 89:10593-10597.

Thanos S, Bonhoeffer F (1984) Development of the transient ipsilateral retinotectal projections in mono-ophthalmic chick embryos. J Comp Neurol 224:407-414.

Williams CV, McLoon SC (1991) Elimination of the transient ipsilateral retinotectal projection is not solely achieved by cell death in the developing chick. J Neurosci 11:445-453.

Williams CV, Nordquist D, McLoon SC (1992) Expression of nitric oxide synthase in the developing visual system of the chick. Soc Neurosci Abstr 18:946.

Wu HH, McLoon SC (1993) Inhibition of nitric oxide synthesis reduced the loss of a transient projection in the developing visual system. Soc Neurosci Abstr 19:42. 